\title{
Effect of Sex on Some Biochemical and Hematological Parameters in Healthy Boer x Hair Goat Crossbreed
}

\author{
Özgür Yaşar ÇELİK*1, Kıvanç İRAK², Gülşah AKGÜL¹ \\ 1 Siirt University, Faculty of Veterinary Medicine, Department of Internal Medicine, Siirt-TURKEY \\ ${ }^{2}$ Siirt University, Faculty of Veterinary Medicine, Department of Biochemistry, Sïrt-TURKEY
}

\begin{abstract}
The aim of this study was to determine some hematological and biochemical parameters in male and female Boer $\mathrm{x}$ hair goat crossbreed $(\mathrm{n}=34)$. Blood samples were collected from the jugular vein in sample tubes with and without anticoagulants. A Mindray BC2800 fully-automated device was used to measure the WBC, RBC, Hgb, Hct, $\mathrm{MCV}$, and $\mathrm{MCH}$ values and ADVIA 1800 brand auto-analyzer was used to obtain $\mathrm{Na}, \mathrm{K}, \mathrm{Cl}, \mathrm{Mg}, \mathrm{Ca}$, Crea, Tp, Alb, Gluo, Chol, Trig, AST, ALT, and ALP values. WBC ( $<<0.01), \operatorname{RBC}(\mathrm{p}<0.05)$, HCT $(\mathrm{p}<0.01)$ and MCV $(p<0.05)$ levels were found to be statistically higher in female specimens, while HGB and MCH levels were found to be statistically identical for both sexes. Meanwhile, males had statistically higher levels of $\mathrm{K}(\mathrm{p}<0.001)$ and $\mathrm{Mg}$ $(p<0.01)$ levels compared to females. Crea $(p<0.001)$, Tp ( $p<0.05)$, Alb $(p<0.05)$, Gluo $(p<0.001)$ levels were also statistically higher in males, while Chol level was statistically higher in females $(\mathrm{p}<0.001)$. No statistically significant variation was detected between the Trig values of the sexes. ALT, ALP activities of males were found to be statistically higher in males than in females $(\mathrm{p}<0.05)$. The results of the study revealed that some hematological and biochemical parameters of Boer $\mathrm{x}$ hair goat crossbreeds are affected by sex.
\end{abstract}

Keywords: Boer x Hair goat crossbreed, Biochemical and Hematological Parameters, Sex.

\section{Sağlıklı Boer x Kıl Keçisi Melez Irklarında Cinsiyetin Bazı Hematolojik ve Biyokimyasal Parametreler Üzerine Etkisi}

ÖZ

Bu çalışmada, erkek ve dişi Boer x Kıl keçisi melezlerinde bazı hematolojik ve biyokimyasal parametrelerin belirlenmesi amaçlandı. Hayvanların vena jugularisinden antikoagulanlı ve antikoagulansız tüplere kan örnekleri alındı. WBC, RBC, Hgb, Hct, MCV, MCH değerleri Mindray BC2800 tam otomatik kan sayım cihazında, Na, K, $\mathrm{CI}, \mathrm{Mg}, \mathrm{Ca}$, Crea,Tp, Alb, Gluo, Chol, Trig, AST, ALT ve ALP analizleri ADVIA 1800 marka otoanalizörde yapıldı. WBC $(p<0.01), R B C(p<0.05)$, HCT $(p<0.01)$ ve MCV $(p<0.05)$ düzeylerinin dişilerde erkeklere göre istatistiksel olarak daha yüksek olduğu, HGB, MCH düzeyleri karşılaştırıldığında ise istatistiksel olarak iki cinsiyet arasında fark olmadığı belirlendi. $\mathrm{K}(\mathrm{p}<0.001)$ ve $\mathrm{Mg}(\mathrm{p}<0.01)$ seviyeleri erkeklerde dişilere göre daha yüksek tespit edildi. Erkeklerde Crea ( $\mathrm{p}<0.001)$, Tp ( $\mathrm{p}<0.05)$, Alb ( $\mathrm{p}<0.05)$, Gluo $(\mathrm{P}<0.001)$, düzeyleri dişilere göre yüksek, Chol seviyesi ise dişilerde erkeklerden istatistiksel olarak yüksek bulundu $(\mathrm{p}<0.001)$. Cinsiyetler arasinda Trig değerleri bakımından fark tespit edilmedi. ALT $(\mathrm{p}<0.05)$, ALP $(\mathrm{p}<0.05)$ aktiviteleri karşılaştırıldığında erkek hayvanların dişilere göre daha yüksek değerlere sahip olduğu belirlendi. Sonuç olarak, Boer x Kıl keçisi melezlerine ait bazı hematolojik ve biyokimyasal parametrelerin cinsiyetten etkilendiği, bazılarında ise cinsiyet faktörünün etkili olmadığ belirlendi.

Anahtar Kelimeler: Boer x Kıl Keçisi, Biyokimyasal ve Hematolojik parametreler, Cinsiyet.

To cite this article: Celik. Ö.Y. Irak K. Akgül G. Effect of Sex on Some Biochemical and Hematological Parameters in Healthy Boer x Hair Goat Crossbreed. Kocatepe Vet J. (2019) 12(1):45-51

Submission: 16.10.2018 Accepted: 31.12.2018 Published Online: 16.02 .2019

ORCID ID; ÖYÇ: 0000-0001-6365-2688, Kİ: 0000-0001-9765-0330, GA: 0000-0003-4804-6502

*Corresponding author e-mail: oyc@siirt.edu.tr 


\section{INTRODUCTION}

Sheep and goat farming have an important place in Turkey's economy. According to the June 2017 data of the Turkey Statistics Institute (TÜIK), 11 million goats exist in Turkey, 464 thousand of which are positioned in the city of Siirt (Anonymous 2018). While numerous native goat breeds are being raised in different places of Turkey based on the particular location's geographical configuration and climatic conditions, the studies are also being carried on to obtain highyield crossbreed breeds. Approximately 98\% of goats in Turkey are hair goats (Anonymous 2018). In addition to being a combined-product breed, the hair goats have high adaptability to insufficient care and nutrition, and to severe environmental conditions; thus they are bred in all regions of Turkey (Bolacali et al. 2017b).

The Boer goat breed was developed in South Africa and was then brought forth to Europe (Casey and Van Niekerk 1988). The most important characteristics of Boer goats are their high genetic potential, extraordinary resistance against diseases, and their ability to adapt to arid climatic and harsh conditions (Malan 2000). Boer goats were imported by numerous countries as a means to increase their overall meat production levels. Boer goats often have been crossbred with Spanish, Ankara, and Nubian goat breeds (Malan 2000; Urge et al. 2004). There were also studies to crossbreed hair and Boer goats in Turkey (Bolacali et al. 2017a; Bolacali et al. 2017b). The determination of the reference values for hematological and biochemical parameters of healthy animals offers valuable reference data for the veterinarian, and are influential in early diagnosis, etiology, and clinical outcome of diseases. Numerous variables like nutrition, stress, temperature, climate conditions, diseases, amount of muscular activity, age, sex, and breed may actively influence the blood parameter levels (Awah and Nottidge 1998; Gündüz 2000; Haliloğlu and Cinar 2004).

Determination of reference values of blood parameters for various breeds is also important. Due to this fact, many studies in the literature inspect biochemical and hematological parameter levels for numerous goat breeds cultivated at various locations all around the world (Rastogi and Singh 1990; Mbassa and Poulsen 1993; Kumar et al. 1997; Azab and Abdel-Maksoud 1999; Njidda et al. 2013). While there are some studies conducted in Turkey about the determination of various hematological and biochemical parameters in Kilis (Iriadam 2004), Siirt hair (Tanritanır et al. 2010), and Ankara goats (Asskın 2013), no such studies exist for Boer $\mathrm{x}$ hair goat crossbreeds. The aim of this study was to investigate some hematological and biochemical blood parameters in male and female Boer $\mathrm{x}$ hair goat crossbreeds.

\section{MATERIALS and METHODS}

\begin{abstract}
Animal Material
All applicable international, national, and/or institutional guidelines for animal testing, welfare, animal care and use of animals were taken into account and followed by the authors. The material of the study consisted of 17 male (min: 621, max: 687, mean: 663.71 days old), and 17 nonpregnant female (min: 616, max: 689, mean: 663.94 days old) a total of 34 goats raised in Siirt province. All animals were raised under similar condition through intensive ad-libitum breeding in a goat farm. The female goats allocated in the study were never been pregnant before.
\end{abstract}

\section{Hematological and Biochemical Analyzes}

Blood samples were collected from jugular veins of animals in the morning into the sample tubes both with and without an anticoagulant. A fullyautomated blood panel device (Mindray BC2800, China) was used to measure white blood cell (WBC), red blood cell (RBC), hemoglobin (Hbg), hematocrit (Hct), mean corpuscular volume $(\mathrm{MCV})$, mean corpuscular hemoglobin $(\mathrm{MCH})$ values in the sample tubes with an anticoagulant.

Meanwhile, the samples in the tubes without an anticoagulant were kept in room temperature for 30 minutes, followed by a 10 -minute centrifugation in $3000 \mathrm{rpm}$, after which the serum were transferred into Eppendorf tubes. The sera in these tubes were analyzed using an auto-analyzer (Siemens, ADVIA 1800, Germany) to determine the sodium $(\mathrm{Na})$, potassium $(\mathrm{K})$, chloride $(\mathrm{CI})$, magnesium $(\mathrm{Mg})$, calcium $(\mathrm{Ca})$, Creatinine (Crea), total protein (Tp), albumin (Alb), glucose (Gluo), cholesterol (Chol), triglyceride (Trig), Aspartate Aminotransferase (AST), Alanine Aminotransferase (ALT), and Alkaline Phosphatase (ALP) levels.

\section{Statistical Analysis}

The obtained data were analyzed using the SPSS 22 package software. Independent Sample T-test was used to determine the statistical variance between male and female group. Results are given as mean \pm SEM (Standard Error Mean). Differences were considered significant when $\mathrm{p}$ values were less than 0.05 .

\section{RESULTS}

Table 1 displays the results of tested hematological parameters for male and female Boer $\mathrm{x}$ hair goat crossbreds. WBC $(\mathrm{p}<0.01), \mathrm{RBC}(\mathrm{p}<0.05)$, Hct $(\mathrm{P}<0.01)$, and MCT $(\mathrm{P}<0.05)$ levels of female 
specimens were found to be statistically higher compared to males', while $\mathrm{Hgb}$ and $\mathrm{MCH}$ levels were found to be not statistically different between gender.

Table 2 displays the results of biochemical parameters in male and female Boer $x$ hair goat crossbreds. While $\mathrm{K}(\mathrm{p}<0.001)$ and $\mathrm{Mg}(\mathrm{p}<0.01)$ levels of male specimens were found to be statistically higher compared to females, no statistical difference was detected in the $\mathrm{Na}, \mathrm{Cl}, \mathrm{Ca}$ levels between the sexes. Males had statistically higher Crea $(\mathrm{p}<0.001)$, Tp $(\mathrm{p}<0.05)$, Alb $(\mathrm{p}<0.05)$, Gluo $(p<0.001)$ levels compared to females, while females had statistically higher Chol $(\mathrm{p}<0.001)$ level compared to males. No statistical difference was detected in the Trig levels between the sexes. Finally, the ALT $(p<0.05)$, and ALP $(p<0.05)$ levels of the male specimens were found to be significantly higher compared to females. No statistically significant variation was detected in AST values.

\section{DISCUSSION}

It was reported that hematological and biochemical parameters of animals may vary based on factors like breed, age, and sex (Iriadam 2004; Niidda et al. 2013; Simsek et al. 2015). Determination of the reference levels for these parameters for various animal species or breeds present important guidelines for veterinary practitioners (Aşkın 2013). For goats, the WBC level was reported to be between 4000-13000 $\mu \mathrm{L}$ (Schalm et al. 1975; Kramer 2000), and the findings of the present study are higher than these values. WBC levels were determined for Kano Brown goats as 18.3 $\pm 0.65\left(\mathrm{x} 10^{9} / \mathrm{L}\right)$ for males and 20.3 \pm 1.33 $\left(\mathrm{x} 10^{9} / \mathrm{L}\right)$ for females, while in Borno White goats it was determined as $13.3 \pm 0.6\left(\mathrm{x} 10^{9} / \mathrm{L}\right)$ for males and $33.4 \pm 0.4\left(\mathrm{x} 10^{9} / \mathrm{L}\right)$ for females. The relatively high WBC level for the goats was interpreted as a welldeveloped immune system (Njidda et al. 2013). In our study, the WBC level findings are in line with the findings of (Njidda et al. 2013), and was determined as $(25.28 \pm 1.68)$ in females, higher than that of males $(18.23 \pm 1.1)$. It is possible to evaluate the relatively high WBC levels in Boer x Hair goat crossbreeds as a characteristic property for the breed.

RBC levels of Boer $x$ hair goat crossbreeds in the present study were found to be lower in males $(p<0.05)$ compared to females, and that this difference between sexes is thought to be a characteristic of the breed. Similarly, the RBC levels of male Ankara goats were found to be lower than females $(\mathrm{p}<0.05)$ (Aşkın 2013).
While in this study the hematocrit levels for male and female specimens were within the reference limits of (\%22-38) specified by Schalm et al. (1975), the females' hematocrit value was higher than the males', and the difference was found to be statistically significant $(\mathrm{p}<0.01)$. High hematocrit value indicates either an increase in the RBC count in the circulation, or the decrease in the plasma volume (Aşkin 2013). The increase of hematocrit percentage in the present study is in accordance with the increase in RBC count. In Borno White goats (Njidda et al. 2013) and in healthy Ankara goats (Aşkin 2013), the hematocrit percentages of females were found to be higher than the females', paralleling the findings of our study. In mature (3+ years of age) Kilis goats, the high hematocrit values $(\% 37.60 \pm 1.90)$ were interpreted as a characteristic of the breed (Iriadam 2004). Various researchers have reported the hemoglobin values, and particularly hematocrit values, are affected by the altitude of the animals, and their nutrition (EgbeNwiyi et al. 2000; Adejumo 2004; Addass et al. 2010; Isidahomen et al. 2010).

Schalm et al. (1975) reported on the $\mathrm{MCH}$ and $\mathrm{Hgb}$ reference values for goats as $5.2-8.0 \mathrm{pg}$ and 8-12 $\mathrm{g} / \mathrm{dL}$, respectively. In the present study, the $\mathrm{MCH}$ and $\mathrm{Hgb}$ levels of male specimens were found as $7,59 \pm 0,82 \mathrm{pg}$ and $11,36 \pm 1,35 \mathrm{~g} / \mathrm{dL}$ respectively, and the females' $\mathrm{MCH}$ and Hgb levels were determined as 6,94 $\pm 0,11 \mathrm{pg}$ and $11,22 \pm 0,31 \mathrm{~g} / \mathrm{dL}$ respectively. All of these results are within the reported reference values and no statistically significant variation between sexes was detected for these parameters. This result is in line with the results of the study of Elitok (2012), who reported no statistical difference in terms of $\mathrm{MCH}$ and $\mathrm{Hgb}$ levels between male and female Saneen goats older than 8 months.

The reference value for MCV for goats is reported as 16-25 g/dL (Schalm et al. 1975). In the present study, the level of MCV in male goats was found to be lower $(15,61 \pm 0,34)$ than the reported reference limits, while it was found to be within the reference limits $(17,01 \pm 0,44)$ for female goats. Adult Ankara female goats were reported to have statistically higher MCV values by Asskın (2013), while Njidda et al. (2013) reported that in Borno White goats (adult males and young females) had statistically higher MCV values compared to their counterparts.

Biochemical parameters help veterinary practitioners to evaluate the health condition and metabolic activities of the animals. Factors like sex and age may influence the physiologic levels of the blood parameters (Yigit et al. 2002; Bozdoğan et al. 2003; Cenesiz et al. 2011). The reference values for $\mathrm{Na}, \mathrm{Cl}$, and $\mathrm{Ca}$ levels of goats have been reported 
as 142-166 mmol/L, 98-110 mmol/L, and 8,9-11,7 $\mathrm{mg} / \mathrm{dL}$ respectively (Kaneko et al. 1997; Karagül et al. 2000). In the present study, the levels of $\mathrm{Na}, \mathrm{Cl}$, and $\mathrm{Ca}$ of the specimens were found to be perfectly within the reference values given in the literature, and no significant differences were detected between the sexes in this regard.

Serum K levels of males were reported to be statistically higher than those of females in Kano Brown, Borno white, and Sokoto red goats by Njidda et al. (2013), and for Ankara goats by Aşkın (2013). The findings of the present study are concordant to the findings of the studies of Niidda et al. (2013) and of Aşkin (2013). Serum K levels were higher in male Boer x Hair goat crossbreeds compared to females', which could be surmised as a racial characteristic. A literature survey has revealed that only a few studies had inspected $\mathrm{Mg}$ levels in goats. The mean $\mathrm{Mg}$ levels of specimens determined in the present study were lower than the reference values of 2,8 -3,6 $\mathrm{mg} / \mathrm{dL}$ reported by Karagül et al. (2000). Male specimens having lower $\mathrm{Mg}$ values compared to females, however, they are in accordance with the findings of Asskın (2013).

The serum creatinin levels are affected by factors like the muscle mass, glomerular filtration, and tubular reabsorption (Guignard and Drukker 1999; Otukesh et al. 2012). In the present study, the comparison of male and female specimens reveals a similar relative height of male creatinin levels compared to females, which was found to be statistically significant $(p<0.001)$, in line with other studies in literature (Aşkin 2013; Njidda et al. 2013). It is possible to interpret the lower amounts of creatinin level in females to the lower muscle mass, which results in lower secretion of creatinin (Alex and Laverne 1983).

Kaneko et al. (1997) and Karagül et al. (2000) have reported the total protein and albumin values as 6 $7 \mathrm{mg} / \mathrm{dL}$ and $2,7-3,9 \mathrm{mg} / \mathrm{dL}$ respectively. The findings of the present study are within these reference values, and both parameters were found to be statistically higher in males compared to females $(p<0.05)$. The literature studies also report that Pasmina (Sharma et al. 1990) and Raini (Sakha et al. 2009) goats' total protein levels vary between sex and are lower in adult females compared to adult males.

Kaneko et al. (1997), Karagül et al. (2000) and Mert (1996) have reported a glucose level varying between 50 and $75 \mathrm{mg} / \mathrm{dL}$ for goats. In the present study, the females' blood glucose levels $(52,82 \pm 2,51 \mathrm{mg} / \mathrm{dL})$ were within the reference limits given in the literature, while males' $(101,06 \pm 6,29 \mathrm{mg} / \mathrm{dl})$ were higher. The statistically relevant $(\mathrm{p}<0.001)$ difference between the glucose levels of sexes might be related to the metabolism differences.

Blood cholesterol level reference limits for goats have been reported as $55-200 \mathrm{mg} / \mathrm{dL}$ in the literature (Karagül et al. 2000). In the present study, the female specimens' cholesterol levels were within the reference values, while males were lower $(\mathrm{p}<0.001)$. Female Saneen (Elitok 2012) and Kano brown and Sokoto red goats (Njidda et al. 2013) were also reported in the literature to have higher cholesterol levels compared to males. Alex and Laverne (1983) have reported that cholesterol levels are influenced by breed, sex, and age.

Elitok (2012) reports that female Saanen goats older than 8 months raised in Afyonkarahisar have higher triglyceride levels compared to males and that the triglyceride level variation between the sexes is statistically insignificant $(p>0.05)$. The findings of the present study are in accordance with the findings of Elitok (2012).

AST is present in numerous tissues of the body but is mostly concentrated in skeletal muscles, cardiac muscles, and in the liver, and its amount can be used as an indicator of tissue damage. Liver damage increases the ALT activity levels. On the other hand, ALP is present in the liver, bones, kidneys, intestines, and placenta, in the form of isoenzyme groups. It is important to determine the cause of the ALP increase for accurate diagnosis. ALP is known as the most sensitive indicator for cholestasis (Mert 1996). In our study, both sexes had lower AST (167-513 U/L) and ALT (24-83 $\mathrm{U} / \mathrm{L})$ activities compared to the values reported in the study of Mert (1996), while the ALP activity levels (93-387 U/L) were within the reference values.

As a result, it was determined that some hematological and biochemical parameters were affected by gender in Boer x Hair goat crossbreeds. The results of this study will hopefully provide useful quide for further studies that will be conducted on Boer x Hair Goat crossbreeds. 
Table 1. Results of hematological parameters in male and female Boer $\mathrm{x}$ hair goat crossbreds

\begin{tabular}{|c|c|c|c|}
\hline Parameters & Gender & Mean \pm SEM & P Values \\
\hline \multirow{2}{*}{ WBC (x109/L) } & Male & $18.23 \pm 1.1$ & \multirow{2}{*}{ ** } \\
\hline & Female & $25.28 \pm 1.68$ & \\
\hline \multirow{2}{*}{$\mathrm{RBC}\left(\mathrm{x} 10^{12} / \mathrm{L}\right)$} & Male & $16.12 \pm 0.31$ & \multirow{2}{*}{ * } \\
\hline & Female & $17.60 \pm 0.50$ & \\
\hline \multirow{2}{*}{ HCT (\%) } & Male & $25.13 \pm 0.76$ & \multirow{2}{*}{ ** } \\
\hline & Female & $28.99 \pm 0.87$ & \\
\hline \multirow{2}{*}{$\mathrm{MCH}(\mathrm{pg})$} & Male & $7.59 \pm 0.82$ & \multirow{2}{*}{ NS } \\
\hline & Female & $6.94 \pm 0.11$ & \\
\hline \multirow{2}{*}{ HGB (g/dL) } & Male & $11.36 \pm 1.35$ & \multirow{2}{*}{ NS } \\
\hline & Female & $11.22 \pm 0.31$ & \\
\hline \multirow{2}{*}{$\mathrm{MCV}(\mathrm{fL})$} & Male & $15.61 \pm 0.34$ & \multirow{2}{*}{ * } \\
\hline & Female & $17.01 \pm 0.44$ & \\
\hline
\end{tabular}

NS: non-significant (p>0.05), ${ }^{*}: \mathrm{p}<0.05,{ }^{* *}: \mathrm{p}<0.01$

Table 2. The results of biochemical parameters in male and female Boer $\mathrm{x}$ hair goat crossbreds

\begin{tabular}{|c|c|c|c|}
\hline Parameters & Gender & Mean \pm SEM & P Values \\
\hline \multicolumn{4}{|c|}{ MINERALS } \\
\hline \multirow{2}{*}{$\mathrm{Na}(\mathrm{mmol} / \mathrm{L})$} & Male & $144.24 \pm 0.64$ & \multirow{2}{*}{ NS } \\
\hline & Female & $142.29 \pm 1.75$ & \\
\hline \multirow{2}{*}{$\mathrm{CI}(\mathrm{mmol} / \mathrm{L})$} & Male & $103.47 \pm 0.80$ & \multirow{2}{*}{ NS } \\
\hline & Female & $100.65 \pm 2.04$ & \\
\hline \multirow{2}{*}{$\mathrm{Ca}(\mathrm{mg} \backslash \mathrm{dL})$} & Male & $8.12 \pm 0.09$ & \multirow{2}{*}{ NS } \\
\hline & Female & $8.43 \pm 0.37$ & \\
\hline \multirow{2}{*}{$\mathrm{K}(\mathrm{mmol} / \mathrm{L})$} & Male & $6.28 \pm 0.19$ & \multirow{2}{*}{ **** } \\
\hline & Female & $4.18 \pm 0.19$ & \\
\hline \multirow{2}{*}{$\mathrm{Mg}(\mathrm{mg} \backslash \mathrm{dL})$} & Male & $2.45 \pm 0.08$ & \multirow{2}{*}{$* *$} \\
\hline & Female & $2.22 \pm 0.03$ & \\
\hline \multicolumn{4}{|c|}{ METABOLITES } \\
\hline \multirow{2}{*}{ Crea $(\mathrm{mg} / \mathrm{dL})$} & Male & $0.88 \pm 0.04$ & \multirow{2}{*}{ *** } \\
\hline & Female & $0.57 \pm 0.03$ & \\
\hline \multirow{2}{*}{$\mathrm{Tp}(\mathrm{g} / \mathrm{dL})$} & Male & $7.22 \pm 0.12$ & \multirow{2}{*}{$*$} \\
\hline & Female & $6.34 \pm 0.33$ & \\
\hline \multirow{2}{*}{$\mathrm{Alb}(\mathrm{g} \backslash \mathrm{dL})$} & Male & $3.46 \pm 0.04$ & \multirow{2}{*}{ * } \\
\hline & Female & $2.98 \pm 0.18$ & \\
\hline \multirow{2}{*}{ Gluo (mg $\backslash \mathrm{dL}$ ) } & Male & $101.06 \pm 6.29$ & \multirow{2}{*}{$* * *$} \\
\hline & Female & $52.82 \pm 2.51$ & \\
\hline \multirow{2}{*}{ Chol (mg $\backslash \mathrm{dL})$} & Male & $46.76 \pm 2.66$ & \multirow{2}{*}{ *** } \\
\hline & Female & $66.18 \pm 4.05$ & \\
\hline \multirow{2}{*}{ Trig (mg/dL) } & Male & $19.59 \pm 1.95$ & \multirow{2}{*}{ NS } \\
\hline & Female & $26.24 \pm 2.86$ & \\
\hline \multirow{3}{*}{ AST $(\mathrm{U} \backslash \mathrm{L})$} & ENZ & & \\
\hline & Male & $69.29 \pm 2.10$ & \multirow{2}{*}{ NS } \\
\hline & Female & $66.59 \pm 3.98$ & \\
\hline \multirow{2}{*}{$\operatorname{ALT}(\mathrm{U} \backslash \mathrm{L})$} & Male & $20.71 \pm 0.56$ & \multirow{2}{*}{$*$} \\
\hline & Female & $18.35 \pm 1.00$ & \\
\hline \multirow{2}{*}{$\operatorname{ALP}(\mathrm{U} \backslash \mathrm{L})$} & Male & $185.35 \pm 12.82$ & \multirow{2}{*}{$*$} \\
\hline & Female & $139.47 \pm 14.16$ & \\
\hline
\end{tabular}

NS: non-significant $(\mathrm{p}>0.05),{ }^{*}: \mathrm{p}<0.05,{ }^{* *}: \mathrm{p}<0.01,{ }^{* * *}: \mathrm{p}<0.001$ 


\section{ACKNOWLEDGEMENT}

The study has been orally presented in the "III International Conference on Engineering and Natural Science" May 3-7 2017, Budapest, Hungary. All applicable international, national, and/or institutional guidelines for the care and use of animals were followed.

\section{REFERENCES}

Addass P, Midau A, Babale D. Haemato-biochemical findings of indigenous goats in Mubi Adamawa State, Nigeria. Journal of Agriculture and Social Sciences. 2010; 6 (1): 14-16.

Adejumo D. Performance, organ development and hematological indices of rats fed sole diets of graded levels of cassava flour and soybean flour (soygari) as substitutes for energy and protein concentrates. Tropical Journal of Animal Science. 2004; 7: 57-63.

Alex K, Laverne L. Clinical chemistry; interpretation and Techniques, Seatle, Washington 1983.

Anonymous.

http://www.tuik.gov.tr/PreIstatistikTablo.do?istab_id=6 82; Accessien date: 08.08.2018

Aşkın I. Evaluation of haematological and biochemical parameters of healthy Angora goats. (Master Thesis), Kirkkale University Institute of Health Sciences, Kırkkale, 2013.

Awah J, Nottidge H. Serum biochemical parameters in clinically healthy dogs in Ibadan. Trop. Vet. 1998; 16: 123-129.

Azab ME, Abdel-Maksoud HA. Changes in some hematological and biochemical parameters during prepartum and postpartum periods in female Baladi goats. Small Ruminant Research. 1999; 34 (1): 77-85.

Bolacali M, Öztürk Y, Yilmaz O, Küçük M, Karsli MA. Effect of genotype and non-genetic factors on growth traits and survival rates in Turkish indigenous Hair goats and their first cross with Boer bucks. Indian Journal of Animal Research. 2017a; 51 (6): 975-981.

Bolacali M, Öztürk Y, Yilmaz O, Küçük M, Karslı MA. Investigation of Some Morphological Traits of Boer $\mathrm{x}$ Hair F1 Crossbred and Pure Hair Goat Kids Raised in Semi-Intensive Conditions. International Journal of Morphology. 2017b; 35 (4).

Bozdoğan Ö, Çenesiz M, Kaya M, Kamiloğlu N. The effect of age, sex, housing system and pregnancy on some blood parameters of tuj sheep. Turk J Vet Anim Sci. 2003; 27: 521-524.

Casey N, Van Niekerk W. The Boer goat. I. Origin, adaptability, performance testing, reproduction and milk production. Small Ruminant Research. 1988; 1 (3): 291 302.

Cenesiz M, Cenesiz S, Yarım G, Nisbet C. Changes in Hematologic and Biochemical Values of Water Buffaloes Indifferent Ages, Sexes and During the Pregnancy Bred in Samsun Province. YYU Vet. Fak. Derg. 2011; 22 (1): $1-4$.

Egbe-Nwiyi T, Nwaosu S, Salami H. Haematological values of appararently healthy sheep and goats as influenced by age and sex in arid zone of Nigeria. African Journal of Biomedical Research. 2000; 3 (2): 109-115.

Elitok B. Reference values for hematological and biochemical parameters in Saanen goats breeding in Afyonkarahisar province. Kocatepe Veteriner Dergisi. 2012; 5 (1): 7-11.

Guignard J-P, Drukker A. Why do newborn infants have a high plasma creatinine? Pediatrics. 1999; 103 (4): e49-e49.

Gündüz $\mathbf{H}$. The seasona changes of some biochemical parameters in holstein cows. YYU Vet. Fak. Derg. 2000; 11: 50-53.

Haliloğlu S, Cinar M. The effect of sex on some blood biochemical parameters in Geese. Indian veterinary journal. 2004; 81 (12): 1413-1414.

Iriadam M. Some haematological and biochemical parameters in Kilis goat. Ankara Üniv Vet Fak Derg. 2004; 51: 83-85.

Isidahomen E, Ikhimioya I, Njidda A, Okoruwa M. Haematological parameters and Blood chemistry of different species of Ruminant animals in Humid Tropical environment. Nigeria Agricultural Journal. 2010; 3: 85-90.

Kaneko J, Harvey J, Bruss M. Clinical Biochemistry of Domestic Animals, Academic Press. 1997.

Karagül H, Altıntaş A, Fidancı U, Sel T. Clinical Biochemistry (In Turkish), Medisan Yayın Evi, Ankara. 2000.

Kramer J. Normal Hematology of cattle, sheep and goats, In: Scahlm Veterinary Hematology, F. Bernard, G. Joseph, C. Nemi, \& W. John (Ed.),^(Eds.), 5 ed., Lippincott Williams \& Wilkins, USA. 2000; pp. 1075-1084

Kumar N, Rastogi S, Singh S, Tyagi S. Variations in leucocytic count and some plasma biochemical constituents due to age and sex in Gaddi goats. Indian Journal of Animal Sciences. 1997; 67 (4): 312-313.

Malan S. The improved Boer goat. Small Ruminant Research. 2000; 36 (2): 165-170.

Mbassa G, Poulsen J. Reference ranges for clinical chemical values in Landrace goats. Small Ruminant Research. 1993; 10 (2): 133-142.

Mert N. Veterinary Clinical Biochemistry (In Turkish), Ceylan Matbaacillk Ltd.Sti, Bursa. 1996.

Njidda A, Hassan I, Olatunji E. Haematological and biochemical parameters of goats of semi arid environment fed on natural grazing rangeland of Northern Nigeria. Journal of Agriculture and Veterinary Science. 2013; 3 (2): 2319-2380.

Otukesh H, Hoseini R, Rahimzadeh N, Hosseini S Glomerular function in neonates. Iranian journal of kidney diseases. 2012; 6 (3): 166.

Rastogi S, Singh S. Normal hemogram and blood analytes of mountain Gaddi goats. Indian Journal of Animal Sciences. 1990; 60 (11): 1338-1339.

Sakha M, Shamesdini M, Mohamad-Zadeh F. Serum biochemistry values in Raini goat of Iran. Internet Journal of Veterinary Medicine. 2009; 6 (1).

Schalm O, Jain N, Carroll E. Normal values in blood morphology with comments on species characteristics in response to disease. Veterinary Hematology, ed. 1975; 3: 82-218.

Sharma B, Biswas J, Lal M. Some biochemical parameters in serum of Cheghu goats. Indian Journal of Animal Sciences. 1990; 60 (11): 1340-1341.

Simsek Ö, Karaşahin T, Güner B, Dursun Ş. Some Haematological and Biochemical Parameters in Hasak and Hasmer Crossbred Sheep. Atatürk Univ. Vet. Bil. Derg. 2015; 10 (1): 27-32.

Tanritanır P, Ceylan E, Dede S. The Determination of Some Blood Parameters in Healthy Siirt Hair Goats Before and After Parturation. YYU Vet. Fak. Derg. 2010; 21 (2): $103-$ 105. 
Urge M, Merkel R, Sahlu T, Animut G, Goetsch A. Growth performance by Alpine, Angora, Boer and Spanish wether goats consuming 50 or $75 \%$ concentrate diets. Small Ruminant Research. 2004; 55 (1-3): 149-158.

Yigit A, Kisa Ü, Arikan S, Akçapinar H, Tasdemir U. Influence of age and sex upon blood parameters in Sak1z x Karayaka G1 crossbred sheep. Ankara Üniversitesi Veteriner Fakültesi Dergisi. 2002; 49: 101-106. 